\title{
The Ethics of Love
}

\author{
Alfred Archer ${ }^{1}$ \\ Published online: 5 November 2021 \\ ( ) The Author(s), under exclusive licence to Springer Nature B.V. 2021
}

\section{Contents}

1. Morgan Gagnon - 'The Ethical Potential of Love in the Wake of Sexual Violence'

2. Paddy McQueen - 'Sexual Interactions and Sexual Infidelity'

3. Kamila Pacovská - 'Remorse and Self-love: Kostelnička's Change of Heart'

4. Anca Gheaus - 'Unrequited Love, Self-victimisation and the Target of Appropriate Resentment'

5. Laura Candiotto and Hanne De Jaegher - 'Love In-Between'

6. Roos Slegers - 'The Ethics and Economics of Middle Class Romance: Wollstonecraft and Smith on Love in Commercial Society'

7. Alfred Archer - 'Fans, Crimes and Misdemeanors: Fandom and the Ethics of Love'

\section{Editor's Introduction}

What duties do we owe to people we love, people who love us, and people we have fallen out of love with? Can we be morally blameworthy for our romantic and sexual preferences? While the philosophy of love has long been a focus of philosophical attention (for an overview see Helm 2021), these issues relating specifically to the ethics of love were, until recently, relatively neglected. While philosophers from the past such as Aristotle, Plato, Confucius, Montaigne, Kant, Schopenhauer and Nietzsche all discussed some ethical dimensions of love (see May 2011), this topic has only recently reemerged as a topic of sustained philosophical investigation.

In the recent literature, philosophers have begun to investigate several important issues that relate to the moral principles that ought to govern our romantic, friendship, sexual and other forms of relationship with others. This includes discussions about the ethics of sexual and romantic preferences. This debate has considered, among other topics, whether it is morally wrong to have sexual or romantic

Alfred Archer

A.T.M.Archer@tilburguniversity.edu

1 Tilburg University, Tilburg, Netherlands 
preferences for people from particular ethnic backgrounds (Zheng 2016) and whether it is unjust that some groups of people are desired less than others (O'Shea 2020; Srinivasan 2021). Philosophers have also begun to investigate whether we have a human right to be loved (Liao 2015) or to be free from social deprivation (Brownlee 2020) and whether we have duties to make friends with others (Collins 2013). Similarly, the recent literature has also involved discussions of a number of ethical issues that arise from romantic and sexual relationships such as consent (Dougherty 2013), infidelity (McKeever 2020), the use of love drugs (Earp and Savulescu 2020; Spreeuwenberg and Schaubroeck 2020), and ethical issues that arise at the end of relationships (Lopez-Cantero and Archer 2020). Relatedly, philosophers have also explored the ethical status of relationships that go against conventional heterosexual norms such as homosexuality (MacLachlan 2012), polyamory (Brunning 2018), and asexuality (Brunning and McKeever 2021). While far from a comprehensive overview, this hopefully provides a general idea of the kinds of ethical issues relating to love, sex and relationships that have been the focus of philosophical attention in recent years.

This special issue arises from a workshop on the Philosophy of Love that was held at Tilburg University on the 13th and 14th of February 2020. I would like to thank all the speakers, commentators, and attendees of this workshop. Special thanks to my fellow organizers Wim Dubbink, Martine Prange and Roos Slegers. Special thanks too to Wietske Petrisor who did an excellent job as the student assistant for the workshop and to the production team at Springer, particularly Kavitha Gunasekaran, Saritha Hemanth and Subaysala Ravichandran. Little did we realize as we enjoyed two days of fascinating talks that this would be the last in-person philosophy event that many of us would attend for quite some time. I am glad that the last in-person workshop I attended before a COVID-enforced 18-month break was such an interesting, enjoyable, and memorable one.

While the topic of the workshop was on the philosophy of love more generally, several papers focused specifically on the ethics of love. From these papers, several were invited to submit to this special issue of the Journal of Ethics and six of these made it through the peer-review process. These papers form the bulk of this special issue and include the contributions from Morgan Gagnon, Anca Gheaus, Laura Candiotto and Hanne De Jaegher, Roos Slegers and Alfred Archer. These papers were subject to the journal's standard peer review process, with Alfred Archer serving as the acting associate editor for the papers from Gagnon, Gheaus, and Candiotto and Jaegher. To ensure an impartial review process, the papers from Slegers and Archer were handled by a different associate editor for the journal who was unknown to them.

The contributions from Paddy McQueen and Kamila Pacovská were submitted to the journal independently of this workshop. In McQueen's case, the paper was handled as a normal submission and only after the paper was accepted did I offer McQueen the chance to include his paper in this issue. In Pacovská's case the paper was handled as a submission for the special issue from the start and went through the standard review process for special issue submissions.

The first two papers in this issue examine ethical issues related to love and sex. Morgan Gagnon's 'The Ethical Potential of Love in the Wake of Sexual Violence' 
investigates how people ought to respond to sexual violence committed within their communities or by their loved ones. In such cases, love may make it more difficult to respond appropriately to these offenders. However, these same loving relationships can also play an important role in helping to encourage atonement and moral development from the wrongdoers and wider changes in the community that helped facilitate this harm. This, argues Gagnon, has important consequences for how we should respond to sexual violence.

Paddy McQueen's 'Sexual Interactions and Sexual Infidelity' continues the exploration of the ethics of love and sex by developing an account of the nature of sexual interaction and then using this account to defend a view of the nature of sexual infidelity. According to McQueen, a sexual interaction is an interaction in which two or more people engage in sexual activity together with the aim of satisfying a sexual desire in a mutually supportive way. This account has the implication that a wide range of actions can constitute sexual infidelity, including, perhaps surprisingly, the private use of pornography.

The next two papers investigate the connection between love and reactive attitudes like remorse and resentment. Kamila Pacovská's 'Remorse and Self-love: Kostelnička's Change of Heart' draws on Janáček's opera Jenůfa to argue that self-hatred is not an appropriate response to one's own wrongdoing. Self-hatred, Pacovská argues, is a response that stems from a vicious form of pride and selflove which prevents people from acknowledging their own moral shortcomings. This self-hatred is in part caused by the view many of us have of ourselves as morally virtuous people which is threatened when we act immorally. Instead of self-hatred, Pacovská argues that true remorse focuses on the victim rather than the wrongdoer and involves taking a humbler attitude to one's own moral qualities.

Anca Gheaus' 'Unrequited Love, Self-victimisation and the Target of Appropriate Resentment' examines whether we are justified in feeling resentment when we love someone who does not love us back. According to Carlsson (2018), we are justified in feeling resentment in such cases. Even though we are not wronged here, we are harmed by the fact that the person we love does not love us in return. In response to this line of thought, Gheaus argues that those who do not return our love do not harm us but rather fail to benefit us. This failure to benefit is insufficient to warrant resentment, so we should not resent those we love unrequitedly.

The next two papers investigate the ethics of love from feminist perspectives. In 'Love In-Between' Laura Candiotto and Hanne De Jaegher develop an enactive account of loving which is inspired by Irigaray's (1996) account of love. According to Candiotto and De Jaegher, loving involves participatory sense-making. This means that love involves two people trying to make sense both of each other and the relationship they have with each other. Candiotto and De Jaegher then explore the ethical implications of viewing love in this way, arguing that love should involve a willingness to accept the ways in which the person we love is different from us. Acknowledging difference is seen as the first step for engaging in dialectical processes of transformation. We should also open ourselves up to being changed by those we love and allowing ourselves to be vulnerable with them, so that we can 
better know ourselves and each other. This implies a fundamental transformation in how lovers speak to each other.

Roos Slegers' 'The Ethics and Economics of Middle Class Romance: Wollstonecraft and Smith on Love in Commercial Society' examines the similarity between Adam Smith and Mary Wollstonecraft's philosophies of love. Both philosophers were concerned that commercial societies leave little room for romantic love. According to both Smith and Wollstonecraft, the growth of commerce and the development of the middle class encourages vanity. Men are encouraged to be vain about their wealth power and statues and women are encouraged to be vain about their appearance. This vanity gets in the way of developing human connections with others and so acts an impediment to romantic love. The rather depressing result is that it will be very difficult, according to Smith and Wollstonecraft to develop genuine loving relationships in commercial societies.

The final paper in this volume examines the ethics of fandom. How should fans of celebrities or sports clubs respond when the object of their fandom has behaved immorally? Fandom, Archer argues, shares many features with romantic love such as an appreciation of the particular qualities of the loved one or object of fandom, participation in attachment developing practices and changes to how the fan or lover perceive their beloved. Based on this, Archer argues that fandom can be morally dangerous, as it can encourage fans to provide support for immoral behavior, to adopt an immoral point of view and to engage in acts of retaliation against those who uncover the immorality of the fan's idol. This provides some reason for fans to abandon their fandom. However, it does not necessarily mean that fans have a duty to do so. Fans may instead choose to adopt a critical stance to their idol rather than abandoning their fandom altogether. However, fans have good reason to be cautious about their ability to take a truly critical stance towards their idols.

\section{References}

Brownlee, K. 2020. Being sure of each other: An essay on social rights and freedoms. Oxford: Oxford University Press.

Brunning, L. 2018. The distinctiveness of polyamory. Journal of Applied Philosophy 35(3): 513-531.

Brunning, L., and N. McKeever. 2021. Asexuality. Journal of Applied Philosophy 38(3): 497-517.

Carlsson, U. 2018. Tragedy and resentment. Mind 127(508): 1169-1191.

Collins, S. 2013. Duties to make friends. Ethical Theory and Moral Practice 16(5): 907-921.

Dougherty, T. 2013. Sex, lies, and consent. Ethics 123(4): 717-744.

Earp, B.D., and J. Savulescu. 2020. Love drugs: The chemical future of relationships. Manchester: Manchester University Press.

Helm, B. 2021. Love. In The Stanford encyclopedia of philosophy (Fall 2021 Edition), ed. Edward N. Zalta. https://plato.stanford.edu/archives/fall2021/entries/love/. Accessed 1 Nov 2021

Irigaray, L. 1996. I love to you. Sketch for a felicity within history. Trans. A. Martin. London: Routledge. Liao, S.M. 2015. The right to be loved. New York: Oxford University Press.

Lopez-Cantero, P., and A. Archer. 2020. Lost without you: The Value of Falling out of Love. Ethical Theory and Moral Practice 23(3-4): 1-15.

MacLachlan, A. 2012. Closet doors and stage lights: On the goods of out. Social Theory and Practice 38(2): 302-332.

May, S. 2011. Love: A history. London: Yale University Press. 
McKeever, N. 2020. Why, and to what extent, is sexual infidelity wrong? Pacific Philosophical Quarterly 101(3): 515-537.

O'Shea, T. 2020. Sexual desire and structural injustice. Journal of Social Philosophy. https://doi.org/10. 1111 josp.12385.

Spreeuwenberg, L., and K. Schaubroeck. 2020. The non-individualistic and social dimension of love drugs. Philosophy and Public Issues 10(3): 67-92.

Srinivasan, A. 2021. The right to sex. London: Bloomsbury Publishing.

Zheng, R. 2016. Why yellow fever isn't flattering: A case against racial fetishes. Journal of the American Philosophical Association 2(3): 400-419.

Publisher's Note Springer Nature remains neutral with regard to jurisdictional claims in published maps and institutional affiliations. 